\title{
COOKING WITH HUMOUR: A STUDY OF BELARUSIAN HUMOROUS FOLKLORE ABOUT FAMILY COOKING TRADITIONS
}

\author{
Anastasiya Fiadotava \\ Postgraduate student \\ Department of Estonian and Comparative Folklore \\ University of Tartu, Estonia \\ e-mail:zhvaleuskaya@gmail.com
}

\begin{abstract}
This paper is a study of Belarusian humorous folklore revolving around cooking. It examines two different types of folklore text: jokes collected on the internet, and humorous anecdotes in family lore about cooking, the latter collected through fieldwork. By comparing the two kinds of humour, the paper investigates to what extent the values and attitudes manifest in my interviews mirror those found in internet jokes. The research shows that while there can be some parallels between the two types of humour, their forms, topics, and functions differ greatly and reflect separate aspects of Belarusian foodlore.
\end{abstract}

Keywords: cooking, family anecdotes, foodways, humour, jokes

\section{INTRODUCTION}

As a central element of culture, cooking has always been surrounded by folklore and, accordingly, has inspired plentiful folklore research (see, for example, Shosteck 1979; Schofield 1989; Skaarup 2013). These studies mainly explore cooking habits, styles, and rituals within a certain ethnic group, and demonstrate how close the ties between cooking and other aspects of culture are.

However, many localities, including my home country, Belarus, have not yet seen much research on cooking folklore. Belarusian cooking traditions and folklore have generally been studied by ethnologists (see, for example, Korzun 1992 [1976]; Navagrodski 2000) and to a lesser extent by folklorists (Samakhval 2011). Most of these works do not focus on cooking only, but mention it in the broader context of Belarusian cuisine and its manifestations in culture. A significant part of these works are dedicated to traditional dishes and their main ingredients, foodways of Belarusians in the nineteenth and twentieth centuries, 
and dishes that were eaten on special occasions (family and national holidays). Cooking practices have also been discussed in terms of gender distribution, technological aspects, and cooking utensils.

As eating out was (and in most Belarusian families, still is) restricted to special occasions, cooking bears a strong association with home and family. Thus, folklore centred on cooking provides a reflection on family life, gender roles, and values associated with domesticity.

In this paper, I examine the wider implications of cooking through the prism of humorous folklore. While doing so, I outline some of the topics of humorous folklore associated with cooking. I specifically focus on two kinds of humorous folklore: canned jokes circulating online, and family folklore shared with me in the 60 interviews I conducted with Belarusian couples.

The idea behind analysing humour from public, mass-circulation sources and the situational, 'insider' humour of family traditions is to see if the two share the same values and notions of family life. By drawing parallels and identifying differences between the two kinds of humour, I aim to elucidate whether and to what degree the humorous family anecdotes shared by my interviewees display values and attitudes similar to those of internet jokes.

\section{DATA SOURCES AND METHODS}

This paper relies on two main groups of sources. First, I used jokes that were shared online by the users of two of the most popular Belarusian news websites and forums: tut.by and onliner.by. In these forums people can post jokes and react to jokes posted by others. This mechanism of quick joke transmission is, in a way, similar to oral communication (Thielemann 2011: 151). I picked 80 jokes that were related to cooking. In several of these, cooking is mentioned only in passing and does not constitute the core of the joke, although most of the jokes are dedicated primarily to cooking. The majority of the joke narratives that I found were situated in a family setting.

To provide some historical context, I have also used some cooking-related jokes published in the nineteenth century, and Soviet-era joke collections (see, for example, Fiadosik 2005 [1984]; Narodnyja 1961). The former were largely collected by folklorists, while the latter were published for mass consumption. While admittedly a very heterogeneous set in terms of collection and circulation mechanisms, levels of censorship, and the historical context of origin, jokes from the three eras (pre-Soviet, Soviet, present-day) still pertain to the same or similar folklore form and share a similar structure. Moreover, as I show in the 'Jokes about Cooking' section, they display a remarkable continuity in terms of 
both plot elements and embedded values, which creates a basis for comparison and analysis of the recurrent tropes and features.

My second source was humorous family anecdotes gleaned from oral interviews with Belarusian respondents, which I conducted in 2016 and 2017 for a project on humorous dyadic traditions in Belarusian families. By 'family anecdotes' I mean "accounts of events that have taken place within living memory and within one's own family circle" (Holbek 1990: 103). This sample includes 60 interviews with Belarusian couples, with the age of respondents varying between 24 and 66 years. Most of these couples were married officially while some younger couples were in common-law marriage but had been living together for more than a year as of the time of the interview. Some of the interviews involved both the husband and the wife. In cases when interviewing both partners was not possible, I asked my interviewees to discuss the questions of the interview within their family before the actual interview. Interviews were conducted face-to-face or via Skype/Viber. In some cases (when they involved older people living outside the Belarusian capital of Minsk) they were conducted by telephone.

All of my interviewees live in Belarus, with the exception of two couples: one is based in Israel and another in Singapore. Most of the couples live in Minsk, others are from Mogilev, Brest, Slutsk, and Maryina Horka. The interviews were conducted in Russian and Belarusian. All translations used in this paper were made by me.

The interviews primarily focused on family humour, funny personal stories, puns, and humorous rituals shared by family members. I asked respondents to share their humorous memories and funny nicknames with me. I was also trying to establish what kinds of triggers (appearance, peculiarities of speech, hobbies, (in)ability to do something) generate laughter within a family. One of the questions was dedicated to food and cooking related humour. I asked my interviewees to share memories and stories related to cooking, to tell me if and how they laugh at each other's cooking, whether they have any funny traditions related to cooking, and so on. I also asked them about the practical aspects of cooking in their family: who does the cooking, how they divide the responsibilities in the kitchen, whether cooking at weekends and holidays differs from regular cooking. This proved to be one of most rewarding questions: almost every family had a funny story or two to share. The stories often involved self-deprecating humour and were directed towards the story-tellers themselves. However, they also provided a commentary on husband-wife relations and family life in general.

In order to respect the confidentiality of my respondents, I have omitted their names when discussing their stories in the paper. In cases when naming 
is necessary (for example, a husband talks about his wife or vice versa) I refer to my respondents by using pseudonyms.

The two data sources have differences on various levels. Firstly, they differ in terms of genre. Jokes collected from the internet fit more or less to the definition of a joke as a genre: "a short narrative ending in a humorous punch line" (Attardo 2014: 417). Specifically, internet jokes can be categorised as a subclass of canned jokes, i.e., jokes that are "re-created from a pre-existing model the speaker has memorized" (Attardo 2015: 172). Conversely, family lore about cooking manifests in a variety of forms, some of which are difficult to attribute to a particular genre. While there are certain narrative folklore items, there are also funny phrases, quotes, and comments. Canned jokes may also be a part of family lore, but, as I show later on, they are always adapted to the context of a particular family.

Humorous family lore is sometimes difficult to classify as belonging to a specific genre. In many cases such humour fits into the category of dyadic traditions, defined by Elliott Oring (1984: 20) as "behavioral and linguistic routines that are generated, endowed with significance, and maintained within the dyadic relationship", i.e., a relationship between two people, such as wife and husband. In cases when a family consists of more than two people, their humorous family anecdotes cannot be considered dyadic anymore. In some instances, we can speak of dyadic traditions involving two members within a family, in other cases traditions are shared among all family members.

Secondly, the audiences for these folklore sets are different. The readership of canned jokes that are posted on the internet is generally anonymous, so the jokes are mainly rooted in the general cultural background of the users of a particular online community. Consequently, jokes found online are based on generic fictional situations that might take place in the given cultural context, rather than on real-life events. In contrast, in the case of family lore, the audience is never anonymous. Humour is addressed to a particular person and is based on a specific family anecdote. It is extremely context-dependent and cannot always be understood by people outside of the family.

However, these two sets of data still share a very important feature: they are linked by the concept of humour and its mechanisms. Both kinds of humour discussed in the present paper are manifestations of verbal humour, which, according to Raskin's (1985) semantic theory, arises from a coexistence of two opposing semantic scripts. One of the scripts is more obvious than the other and is thus anticipated by the audience, while the other, unexpected script produces a sense of incongruity, leading to a humorous effect. This mechanism is especially evident in the jokes that have a punchline, but can also be applied to family lore. There, humour often emerges when a person's behaviour or words 
fail to meet the expectations of other family members. These expectations may be based on the general cultural context of Belarusian family life, or on a specific situation in a given family. Sometimes incongruity emerges when a usual or well-known phrase is appropriated in an unusual context. This basic underlying principle of humour production means that, for all their formal and contextual differences, online jokes and family lore are fundamentally manifestations of the same phenomenon of verbal humour.

\section{JOKES ABOUT COOKING}

Jokes about cooking have existed in Belarusian folklore since at least the late nineteenth - early twentieth century, when systematic collection of folklore began in the Russian Empire (which at the time encompassed the territory of presentday Belarus). These jokes were rare and mainly mentioned cooking just briefly alongside other domestic chores. In still rarer cases, when cooking was a central activity of these jokes, humorous effect was achieved by showing the woman's (wife's) lack of cooking skills. The following joke may serve as an example:

"Does your young wife cook well?"

"She does cook well; it is just difficult for me to eat it."

(Fiadosik 2005 [1984]: 2301)

Jokes of this time period usually mentioned cooking in the setting of a rural family (or did not specify the setting at all as in the example above), as folklore was mainly collected among Belarusian villagers by researchers such as Alyaksandr Serzhputouski, Eudakim Ramanau, Pavel Shein, and others who conducted their research on behalf of the Russian Geographical Society, which sponsored and coordinated their fieldwork. Cooking is a chore attributed mainly to women. A woman was supposed not merely to be able to cook, but to cook varied and elaborate dishes in order to comply with societal expectations (Navagrodski et al. 2009: 109-110). In humorous folklore of this period of time men take up cooking only in the occasional situation when gender roles are reversed (a husband treats his wife to a meal under some unusual circumstances) and the humour is in fact generated by this role reversal.

Similar jokes existed in the twentieth century, when Belarus became part of the USSR. Soviet authorities strictly censored the jokes that were published and therefore we cannot consider printed folk joke books to be a faithful representation of the oral folklore that circulated at this time (Melnichenko 2014: 34). However, this relates primarily to political jokes, which differed considerably in the official and the alternative discourses. Apolitical jokes (including those about cooking) were not subject to such severe censorship. Consider the following joke: 
"I read in today's newspaper that one should eat more than three kilos of salt each year," a young wife says to her husband at lunch.

"Sure, honey," replies the husband, eating the oversalted soup, "but not all at once!” (Narodnyja 1961: 23)

The jokes that were published in state journals and joke books did not necessarily circulate widely in society. In the case of this joke, however, even if it was not part of the oral tradition at the time of its publication, it has definitely become popular and can still be found on the internet (for example, Anekdoty pro sol') and in oral circulation (I heard a variation of this joke from one of my family members several years ago).

Modern jokes about cooking have inherited much from their nineteenth and twentieth century predecessors. In these jokes cooking is still a woman's role, especially if the woman also happens to be a wife. A woman unable to cook typically remains the butt of the joke:

The husband comes home and sees that his wife is in tears:

"What happened, darling?"

"I baked a cake for you, but Sharik ${ }^{2}$ ate it!"

"Don't you cry darling, I will buy you a new dog."

A wife says to her husband:

"Didn't I ask you not to disturb me? It's your fault that I dropped the cookbook, it slammed shut and now I have no idea what I've cooked for lunch."4

The morning after the wedding. The husband sees his wife in tears in the kitchen.

"What happened, honey?"

"I've been boiling this damn egg for two hours and it is still hard!"

Such representation of cooking within a family is far from unique to Belarusian folk humour: see, for example, Brzozowska (2012: 65) and Laineste (2012: 41) for parallels from Polish and Estonian folklore respectively.

Women can also be mocked for not doing the cooking at all, although it is deemed to be their responsibility:

A busy highway at noon. A woman driving a Mercedes hits the brakes abruptly and a Zaporozhets [a cheap and very basic Soviet-era car] crashes into the back of her car. The driver of the Zaporozhets also happens to be a woman. Which driver is at fault?

Both. They both should have been at home cooking lunch. ${ }^{6}$ 
This is not to say that only women are laughed at due to their lack of cooking skills. Men also sometimes become the butts of the jokes about cooking. However, the focus of these jokes shifts. The humorous effect is often generated by the fact that men cook only occasionally:

After the wedding night the husband wakes up, gets up quietly and goes to the kitchen. He makes coffee and sandwiches, puts them on a tray and brings them to his wife:

"Oh, honey, how sweet of you!"

"See how this is done? Starting tomorrow morning, you will do it every day."

Even when there are two jokes with an almost identical structure (the perfect woman/man), the relationship of the two genders to cooking is portrayed differently:

Four rules for a happy family life: 1. You should find a woman who cooks well and takes good care of the house. 2. You should find a woman who makes a lot of money. 3. You should find a woman who loves sex. 4. These women should never meet each other! ${ }^{8}$

1. It is important to have a man who helps you at home, does the cleaning, sometimes cooks, and has a job. 2. It is important to have a man with a sense of humour. 3. It is important to have a man whom you can trust and who won't lie to you. 4. It is important to have a man with whom you have a good time in bed and who likes you. 5. And the most important thing. It's very, very important. These four men must not know each other ${ }^{9}$

Sometimes the humorous effect is based on the fact that men can cook only the most basic dishes:

I decided [masculine form] to make mashed potatoes and cutlets for dinner, and pancakes as a dessert. So here goes... It's clear how to make mashed potatoes and pancakes, but I'll be making cutlets for the first time... I've looked through lots of different recipes, everyone makes them a bit differently, but I get the gist and will be making pelmeni [meat dumplings widely available in stores as a convenience food and associated with bachelor lifestyle]. ${ }^{10}$

The language that describes cooking activities is also sometimes gender-specific. Terms that refer to cooking can gain a different meaning in men's vocabulary:

Mother is frying cutlets in the kitchen. Vovochka asks her:

"Mum, is a flight attendant a fish or a cutlet?" 
"What kind of question is that?"

"Well, yesterday Dad told his friend over the phone how their entire crew was frying [zharili, a slang for 'have sex with'] a flight attendant."11

Such a difference between a man's and a woman's role in jokes about cooking is not incidental. The situation reflected in jokes mirrors the patriarchal division of labour in the nineteenth and twentieth centuries. This paradigm required the husband to work and earn a living and the wife to stay at home and do the household chores. Even when in the twentieth century it became typical for women to work alongside men, the wife was still the one to do most (if not all) the chores.

However, the emergence and growing popularity of cooking jokes does not simply reaffirm the patriarchal paradigm. It also points to a clash between the traditional model of family life and modernity.

This can be paralleled to the blonde jokes in American humour. Blondes are portrayed in these jokes as stupid and overly sexual. It has been suggested that these jokes emerged in response to a significant change in women's status, whereupon women became active participants in the previously male realm of career-making. In this realm, women had to appropriate a role that was totally different from the one they used to perform (Oring 2003: 58-70). Thus the ultimate focus of blonde jokes is not on the blonde, but on changing values (Davies 2011: 112).

Belarusian jokes about cooking display an opposite trend. Since cooking is regarded as one of the most traditional women's chores, women are mocked when they do not or cannot cook. Men, in contrast, are laughed at when they dabble in cooking. However, the tension between conservative values and the changing reality of family life is resolved in a totally different way from the one in the blonde joke cycle. The blonde as a joke archetype acts too feminine (in a traditionalist sense), failing to adapt to women's new status as actors in a rational world. In contrast, women in cooking jokes are laughed at because they deviate from the feminine ideal of domesticity. Moreover, some of these jokes (for example, the one about the traffic accident) provide a kind of metacommentary on modern reality, which differs greatly from the traditional views on gender roles in Belarusian society. In this way, cooking jokes are not necessarily about cooking as an activity per se, but rather about cooking as a symbol of clearly delineated gender roles. Cooking jokes indicate that the world has changed, but there is still pressure on women to perform their household duties with little help from the men with whom they share the household. 


\section{FAMILY COOKING TRADITIONS}

In this section I provide an overview of the family folklore revolving around cooking, which my interviewees shared with me. By no means do I claim that the patterns I have traced can be considered representative for the entirety of Belarusian society. The sociological diversity of my research is too limited to allow for such claims: most of my interviewees represent the middle class and all of them live in urban (or suburban) areas. I readily acknowledge that family cooking traditions are very likely to differ greatly in other social groups as well as in rural areas.

Yet the aim of this section is not to provide a comprehensive overview of Belarusian family cooking traditions. It is, as I briefly discussed in the methodology section, to see if assumptions about gender roles found in cooking jokes circulating online correspond to the reality of my interviewees' family lives.

Using interviews rather than participant observation supposes a certain degree of subjectivity on the respondents' part, and reflects primarily my interviewees' own perceptions of cooking and a wider role division in their families, as well as relevant societal norms. Consider the following example involving a husband and a wife (both 27 years old). When I asked who does the cooking, the wife replied that the two have breakfast separately but try to eat dinner together, and it is generally cooked by her. Then she said: "At weekends I sometimes make Nikita cook...” Then she immediately corrected herself: "Ask him, not make."

Here we can see the ambiguity of the situation. On the one hand, the husband is probably reluctant to cook at weekends and getting him to do so involves a degree of coercion on the wife's part. On the other hand, she did not want to give the impression of being a 'family dictator' during the interview, so she corrected herself to present the situation in a more cooperative light. This example is fairly typical. As Mats Alvesson explained, an interview is inevitably a process of impression management, where respondents engage in "moral storytelling and promotional activity" in order to construct a positive image of themselves (Alvesson 2003: 21). Given that it is natural for people to stress their good morals, "moral storytelling" cannot be a reason not to rely on one's interviewees. However, it should be taken into account while analysing the interviews. This emic approach to cooking within Belarusian families gives my interviewees a possibility to reaffirm their views on how cooking is (or should) be done in a family.

Out of the 60 families that I interviewed, only in seven cooking was exclusively the wife's domain. In still fewer families did the husbands offer no help with the washing up either. One of my female interviewees told me her husband 
"comes to the kitchen only to eat". This does not mean, however, that husbands not involved in cooking stay away from all domestic chores completely: they may do the cleaning, help with hanging out laundry, and have other household duties. An interesting story came from one of my male interviewees, aged 50, who claimed that he baked a Napoleon cake for his first date with his future wife, but has done nothing at all ever since.

In some of the other families the husband only cooks in the absence of his wife. One of my male interviewees, for example, said that he can cook everything because he often travels on business and has to cook for himself, but he never cooks when his wife is at home.

In many families cooking is divided between husband and wife, but the wife still does the bulk of it. Sometimes the husband cooks only a few 'special' dishes. Several families mentioned pancakes and draniki (Belarusian potato pancakes) as a predominantly male dish. In two of the families the tradition of men cooking pancakes has existed for two generations. There are families where the husband cooks on special occasions (for example, at weekends or in the morning, or when many guests are expected). Interestingly, men's specialising in cooking weekend breakfasts is not unique to Belarusian, or even Slavic family traditions, and can, for example, be found in the United States as well (Adler 1981: 48).

In many cases the division of labour is more pragmatic: the one who has more time at the given moment cooks. This is particularly relevant in families where one or both spouses do not have a fixed 8-hour day schedule. Sometimes the wife and the husband decide that one will cook the main course and the other one the side dish; sometimes one of them starts and the other finishes the cooking. Some of these couples claimed that the division of cooking responsibilities between the husband and the wife is more or less equal; in others, it was the wife who cooked more.

Finally, there were three families that testified that it was mainly (or even almost exclusively) the husband who cooked. Interestingly, unlike most of the families where cooking was the wife's responsibility, all three of them immediately provided a justification (even though I did not ask for it). In one case, the husband explained that he enjoyed cooking (in contrast to his wife who did not like it at all). In the second case, the wife was the breadwinner who spent most of her time at work, while the husband stayed at home and was responsible for all the household chores. In the third case, the wife confessed that she "wasn't brought up for all these chores". She seemed to believe she was unique in this regard and sounded a bit uneasy about not doing cooking at all. When I reassured her that the situation was exactly the same in my family, she showed a degree of relief and even suggested a reason for us not conforming to the do- 
mestic wife ideal: "At this time [in our late teens, I assume] we were too busy studying [to learn to cook]". It is also worth mentioning that in all these cases (including mine), the husband and wife were both under 30 . Given the limited sample, this might be a mere coincidence, but it could also indicate a gradual shift in gender roles in present-day Belarusian families.

As we see, families display a variety of cooking practices that go beyond the stereotypes found in mass-circulation jokes. However, there is some degree of correspondence between jokes and reality: for the most part, cooking does remain the woman's responsibility even though in many families the husband cooks occasionally. That said, many of the stereotypical joke plots seem to be irrelevant, as the husband's involvement in cooking is nothing exceptional and the division of labour is often based on the availability of the spouses more than gender. In the following chapter, I discuss how this relatively new reality manifests in humorous family anecdotes.

\section{HUMOROUS FAMILY ANECDOTES ABOUT COOKING}

Humorous family anecdotes usually have a very different form as compared to folk jokes found online or in joke collections. They are more situational, heavier on implication, and much less fixed in structure. That said, some families I interviewed do use canned jokes to refer to cooking within their family. Here is one of such jokes:

A lady meets a man, treats him to dinner and says:

"That's it, now you are mine [moy]."

He replies:

"Wash it [moy] yourself!" (female, 40)

The interviewee shared this joke to illustrate the fact that in her family she does all the cooking and dish-washing. Her intention when telling the joke seemed not to be to mock her husband; rather, she wanted to describe the cooking situation in her family more vividly.

In another case, a female interviewee of 49 illustrated how her family appropriates and adapts jokes:

A colleague told me a joke at work; I came home and retold it:

The husband opens the fridge and there is nothing inside. He asks the wife:

"What do we have for dinner today?"

"The same as yesterday."

"Is there nothing to eat again?"

"Yeah, I've cooked it for two days." 
I tell this joke to my husband and he says: "Oh, Inna, you've cooked like this for the whole week!"

We tell jokes and then turn them into our own.

Canned jokes are often adapted to a specific context in face-to-face communication (Zajdman 1991). While retaining their basic structure and punchline and thus remaining funny, they are customised to reflect a situation in a particular family rather than some abstract values of an abstract group of joke-tellers and listeners.

In another case my interviewees reported using the following Q\&A joke:

"Would you care for a coffee in bed?"

"No, I would rather have it in a cup." (female, 46)

Sometimes other folklore genres are used to refer to cooking. One example was cited to me by a 25 -year-old husband:

We were cooking draniki not so long ago, and we had to grate a lot of potatoes. We divided the work: I was peeling the potatoes and she was grating them. I finished peeling and said: "Saw it, Ira, saw it". ${ }^{12}$ I like inserting these quotes from The Twelve Chairs ${ }^{13}$.

Here we see an example of how a humorous folklore item that was not originally related to cooking can be applied to it. In this case, the quote refers to both the physical action (grating potatoes is somewhat similar to sawing) and the situation at large (in the novel, the line "Saw, Shura, saw" encouraged the recipient to continue physical work while the utterer did nothing himself).

In most cases, however, family folklore seems to comprise puns, situational humorous remarks, and personal humorous narratives. These genres do not have such precise features as joke (brevity, plot, clear structure, etc.), and can encompass a variety of folklore elements. The content of humorous family anecdotes is also specific: it relies primarily on the family's own experience rather than on widespread plots.

Much like jokes found on the internet, humorous family anecdotes can sometimes be directed towards the spouse who does not know how to cook in general. Unlike internet jokes, however, in the humorous anecdotes of my interviewees I did not see such a clear gender demarcation: it was not necessarily the wife's inability to cook that was mocked; often it was the husband who was made fun of.

Here is an example of when the wife is being laughed at, told by the wife herself: "We joke that on a scale from 0 to 10 , my housewife skills are at -2 " (female, 24). 
And then, from a different family, an ironic account of the husband's cooking skills:

[My] husband could not cook anything before we met. And it was so weird for me, how is it possible, a grown-up person. And so we teach him, have him watch all these culinary shows, and then he tries to cook something. (female, 24)

In some cases, the humour is based on unwillingness rather than inability to cook: "Sometimes I say: 'I have turned on the kettle, now you do everything else" (laughs) (female, 30).

A larger part of the humorous family anecdotes concentrate on specific occasions rather than on inability/unwillingness to cook in general.

In some cases involving the older generation, the spouses share humorous narratives related to the early days of their marriage when the wife could not cook well:

Sure, I always remind her about the time when we had just got married, I came home and saw a note: "The soup is on the stove, but it doesn't taste good, you may not want to eat it". So now I say: "How is it today, can I eat it?” (male, 55)

Another interviewee mentioned specifically that it was his wife's first attempt to cook a specific dish that failed:

I always remind her of the time when she baked her first cake and made blueberry jam. She probably didn't know how to do either. So you could buy a ready-made cake for like three roubles, but we spent fifteen on making one and nobody could eat it. And the blueberry jam, she asked me how long to boil it for. I say: "I don't know, probably a long time". Long story short, the jam appeared to be... Well, it was jam, how can you spoil it... But when my sisters came - I have two twin sisters - they called our mother and said: "Mom, our sister-in-law has made this jam, it's like stick jaw toffee”. She boiled it too long, after all. (male, 58)

Plenty of humorous memories are derived from making (or rather, trying to make) some unusual dish:

I was making this dish called rasstegai: they are small dough pies, but the point is that the upper part is not entirely covered, there is a large hole in the centre, so you can see the filling, and in this hole you pour a bit of broth. So you have this pie with minced meat or fish, there is a hole in upper part and this broth is boiling there, and this pie is so juicy, you can 
hear the broth bubble. That's the ideal scenario. But if you make it for the first time, and on an unfamiliar stove at that, everything opens up, falls apart, the water hisses, doesn't look good at all. The smell is good, though. You take this mess out of the oven and realise you are ashamed to show it to anybody. These rasstegai were supposed to be a surprise for everybody... Well, you never get it right the first time. (female, 50)

Funny situations that become a part of family folklore can also occur when making some regular dish if some incident happens during the cooking:

I was making a barbecue, it's on the barbecue grill, the others said something [about my cooking], and I say: "When you do the cooking, then you do the speaking". And then I turn the meat and accidentally drop it in the coals. They say: "A real chef!" [ironic tone]. And I go: "Indeed I am". It was okay, I took it out, shook off the ash, no big deal, and they ate it and were glad that the chef had made it for them. I said, at least your stool will be solid. (male, 61$)^{14}$

In some cases, humour also derives from a specific habit related to cooking. This could be something like making the porridge too thick or oversalting every dish. In order for such a habit to become a source of humour, there has to be a difference in preferences between family members:

Interviewee: "I like my food extra salty, he likes his undersalted. So he salts the food first, and then each of us additionally salts the contents of our own plates. Otherwise, he knows what to expect if I cook."

Me: "Does he make jokes of you adding too much salt?"

Interviewee: "That I am in love ${ }^{15}$, yes. Or that I am a moose." (female, 27)

Interviewee: "I cook most of the time. Oleg makes pizza and fried meat, but generally I do the cooking."

Me: "Do you make jokes about his cooking when he fries meat or makes pizza?"

Interviewee: "When he makes pizza, it ends up having too much filling, so I say: 'Why do you even need dough there, you could just mix sausage with cheese and with mayo, no dough needed." (female, 25)

Sometimes funny situations occur because of some specific ingredient that is added to the otherwise tasty dish. A typical story involves one of the spouses adding an ingredient that the other one never eats. The humour stems from the fact that this ingredient is discovered only after the spouse has already eaten and enjoyed the meal: 
Generally, we haven't had any incidents, just this one time when I added mushrooms to something, I didn't know that he doesn't like them, and I added mushrooms to a dish that he really likes. Maybe it was pasta sauce. And so he is eating without seeming to realise there are mushrooms there. "Mmm, that's delicious." He seems to like it, then after two minutes he goes: "What's in it, something's wrong there. Everything seems tasty, but something is wrong." And he starts analysing: "Maybe you have added this? Maybe that?" I am sitting there, silent. It should be all right; I didn't add anything special. Then he goes: "Okay, so what don't I like?" (laughs) "So, I don't like mushrooms. Wait, have you added mushrooms?" (laughs). He's already finished it, and then in five minutes he asks: "Wait, have you added mushrooms?" (female, 25)

These examples demonstrate that family cooking humour targets both husbands and wives. The stereotype of cooking as an exclusively female business, despite being so pervasive in internet jokes, is seldom reproduced here. In my interviews I encountered only one narrative in which humour about cooking explicitly referred to gender stereotypes. It was related not specifically to cooking but to household chores in general:

When I have to do the cleaning, or wash the dishes, or something else that, well, it's incorrect to call it a 'female chore', but they are usually considered female chores in our Slavic mindset - when I have to do something like that, I remember my granddad said he had a friend who made fun of his wife and put on a shawl when his wife made him do some of these chores. So when she makes me do it, I always make fun of her: "Bring me a shawl, put it on me, so I won't be ashamed if the neighbours see." (male, 31)

Another trope of humorous family anecdotes, which is related to gender stereotypes, is that the husband only cooks occasionally. Even though a dish may be basic, the husband is always proud of it and the wife is expected to react with awe (but instead often responds with irony):

He cooked meringues recently, these sugar cakes. They are very easy to make, it's quick, but oh how much happiness there was! I come home and he goes: "I have a surprise for you! I've cooked something." I'm all anticipation: "What could it be?" And there are these meringues. He is so proud, stars in his eyes: "I'm your confectioner now!" (laughs) (female, 25)

As we see, humorous family anecdotes about cooking differ significantly from canned jokes found online. As I discussed in the previous section, internet jokes primarily use cooking as a window on gender relations and their changes in 
contemporary Belarusian society, often reproducing traditional gender stereotypes. Humorous family anecdotes, as represented in my interviews, appear to be less focused on gender relations, because for many of the couples cooking has lost its strong gender markedness.

On the other hand, some general humorous plots found in internet jokes can also be identified in humorous family anecdotes about cooking. For example, the notion of the husband cooking only occasionally but taking great pride in his cooking was a recurring motive in family narratives that also exists in canned jokes. My interviewees also occasionally use canned jokes or cite parts of them to comment on their cooking traditions.

While in some cases families make humorous comments on cooking in general (usually by appropriating folk jokes or other folklore genres), the bulk of humorous family anecdotes on the subject revolves around specific experiences and shared memories. Family foodlore draws primarily on the shared experience of the family and only occasionally involves retelling canned jokes. The funniness of this humour is thus predicated on the vividness and personal significance of the experiences that gave birth to it. These personal stories may share some commonalities across different families, but what makes them important is their uniqueness.

\section{REFLECTIONS ON FAMILY COOKING TRADITIONS AND ON (THE ABSENCE OF) HUMOUR}

When conducting interviews about family cooking traditions and family humour, I heard not only my interviewees' accounts of their family folklore, but also their own reflections on it. These reflections can be conceptualised as a form of meta-commentary, in the Geertzian sense, on "the story they [people] tell about themselves" (Geertz 1973: 448). In fact, some of these reflections were humorous themselves.

For example, in one of my interviews, after I asked who cooked in the family, my interviewee, a woman of 56, replied:

My husband makes potatoes, minced meat, stuff that does not require any particular skill; and when it comes to salads and fancier dishes, that's my territory. Stuff he thinks that he can't cook - or prefers to think (laughs). I don't think it takes that much to be honest, beyond willingness to try.

Here the woman points to the incongruity between her husband's 'official' reason not to cook any complicated dishes (he does not know how to do it) and his real reason for it (he does not want to). This incongruity provokes a typical reac- 
tion - laughter. However, the final statement shows that the woman herself does not regard the situation as incongruous: her conclusion gives no room for any alternative interpretation of the previous remark. Laughter is therefore not an indication of a humorous attitude of the woman towards the situation that she describes but rather a marker of irony and incongruity.

Another female of a similar age (54) used a different way to express her ironic attitude to the labour distribution in her family:

Well... it is my prerogative to be in the kitchen all the time. And Andrei's contributions, so to speak, they are so rare. We see them not as humour, but as these precious moments of our family life, this stuffed pike of his, or sometimes he makes ukha [fish soup], these are such exclusive occasions that we tremblingly, tremblingly, so to say, remember them. You cannot joke about these things, they're holy (laughs). A dish from Andrei is like once in three years, how can we joke!

When replying to the question about any funny situations concerning the cooking within their family, she was talking in an overly serious manner. Even though she explicitly stressed the seriousness and even holiness of the situation of her husband cooking, towards the end of the reply she gave way to laughter. This indicates that she was saying the opposite to what she meant, which is a common definition of irony.

Sometimes my interviewees would add a humorous flavour to their family lore spontaneously when discussing it during the interview:

Wife: Generally, I cook the dinner. My husband cooks at weekends. In the morning, throughout the twenty years [of our marriage] my husband has cooked pancakes, omelette...

Husband: It is not a tradition; it is just the inability of some of us to respond adequately to mornings (both interviewees laugh).

Such humour may not be a part of family lore due to its spontaneity, but it demonstrates how the couple's shared knowledge can act as a trigger for humour: in this case, the fact that the wife is not an early riser becomes such a trigger. The humorous tone of the reflection on this fact indicates that the situation is accepted by both spouses.

Such comments provide an insight into the interviewees' emic perception of their families' cooking traditions. Moreover, the humorous and ironic form of these comments gives us an extra layer of meaning. The use of irony helps the speakers to "emphasize specific aspects of the situation" (Barbe 1995: 77), specifically, the unwillingness of their husbands to do regular or complicated cooking. Humour also shows that a certain incongruity exists between the 
women's perceptions of how the cooking could be shared and the way it is actually done. Such an analysis of humour and irony in people's reflections gives the researcher the possibility not only to investigate family folklore but also outline how families reflect on it.

These reflections can also take another direction. It has long been noted that family humour plays an important role in lightening husband-wife relations, and has a therapeutic effect (Arnold 1972: ix). On the other hand, in certain cases family humour may also be destructive (Walsh 2015: 90). In my interviews, there were cases when respondents stressed that they did make jokes about each other's cooking. They cited one or two of the following reasons for this:

Firstly, the spouse who does most of the cooking does it really well.

Me: "Perhaps you had some funny incidents related to cooking?"

Interviewee (male, 36): "No, my wife cooks very, very well, false modesty aside, she knows how and likes to cook, and therefore there are few incidents."

Secondly, making a joke involves the risk of hurting the spouse's feelings and the joke-teller ending up cooking themselves:

Me: "And does he ever joke about your cooking?"

Interviewee (female, 54): "You know, he doesn't risk it."

Me: "Because otherwise he may end up without dinner?"

Interviewee: "Yes, I give him the opportunity: do it better. It's already, you know, this territory where you might simply stay hungry."

Another interviewee, a man of 38, puts it even more explicitly:

My wife cooks well. I constantly praise her, because otherwise next time I'll have to cook myself. I do not joke: it's dangerous (laughs).

In both cases, it is clear that the potential joke-tellers (usually husbands) do not make jokes because they anticipate or fear anger, 'unlaughter' as their spouse's response. "Unlaughter" is defined by Michael Billig (2005: 192) as "a display of not laughing when laughter might otherwise be expected, hoped for or demanded". Therefore, humorous family anecdotes are dependent not only on cooking habits and traditions but also on the potential reaction from the audience, which typically coincides with the joke butt (in contrast to canned jokes with their generic, impersonal joke butts). Moira Smith (2009: 159) argues that in such cases the audience and not the joke-teller plays the primary role in group boundary making and enhancing (or ruining) solidarity. These examples illustrate that in family humour it is important to take into account the whole 
process of husband-wife communication, including its context and the spouses' personalities, and not just focus on the humorous text itself.

\section{CONCLUSION}

Cooking is one of the most important domestic chores and as such is widely reflected in various humorous folklore genres. Mass-circulation jokes shared on the internet use cooking mainly as a lens through which to view gender roles, often reflecting the tension between patriarchal gender roles and the changing values in Belarusian society. In these jokes the act of cooking can be (and in some examples is) substituted by any other domestic chore while retaining the same meaning.

Humorous family anecdotes about cooking differ from such jokes in terms of the form, content, and function. Humour items here can take on hybrid forms (for example, appropriating a canned joke and adding some personal element to it). The content of humorous family anecdotes is diverse and encompasses both general attitudes towards cooking and particular situations that involve preparing food (the latter kind, however, is both more diverse and numerous). Some of the humorous narratives have been recalled for years and even decades while others are built on some recent situation and are soon forgotten. The humorous family anecdotes of every family I interviewed were tightly connected to their traditions of cooking and indicative of the way they reflect upon these traditions. The same distribution of labour may provoke jokes in one family and yet not be found humorous by another.

Sharing humour within a family is much more intimate than sharing a joke on the internet. It also plays a different communicative role. When posting jokes on a dedicated internet forum, people seldom address somebody personally but rather share what they find funny and appropriate with the purpose of entertaining themselves and their large, but invisible, audience. Humorous family anecdotes are much more personal and are not used solely for amusement but also to enhance family ties. Therefore, it puts certain limitations on family folklore traditions. Apart from the fact that they should be rooted in family's experience, they should also take into consideration the reception of the joke by its audience (which is also often the butt of the joke). Failing to do so may in some cases lead to harming the relationship.

Moreover, the study of family humour calls for the study of people's reflections on their folklore. It can provide an emic commentary both on family traditions and on humorous family anecdotes. While it can be humorous itself, the 
humour plays a different role: it helps the interviewees to present their point of view in a more playful, as well as a more articulate, manner.

The study of internet jokes and humorous family anecdotes about cooking is not just the macro- and micro-level of the research of the same phenomenon. While it is possible to identify some topics that resonate in both forms of humour, the difference of context makes it impossible to mechanically extrapolate any conclusions made as regards studying internet jokes to the dimension of humorous family anecdotes, and vice versa. While it seems that humorous family anecdotes are a fairly immediate reflection of the relationships and values adopted in a specific family, the extent to which widely circulating folklore represents current societal values and norms is less obvious, much as the very idea of a collective value system shared by the entire society is problematic. If anything, jokes found on the internet display considerable continuity with jokes from previous eras and appear to be on the conservative side in terms of values. Even though my primary goal was to compare canned jokes and humorous narratives found in family lore, I realised during the research that a comparison between internet jokes about cooking and humorous family anecdotes on the same subject is bound to be a comparison of two totally different systems of reference, each of which functions according to its own rules and principles. It is important to take this into consideration in cases that involve comparison between such diverse folklore forms.

\section{ACKNOWLEDGEMENTS}

This study was supported by the Estonian Ministry of Education and Research (IUT 22-5), and by the European Union through the European Regional Development Fund (Centre of Excellence in Estonian Studies).

\section{NOTES}

1 This joke is cited from Alyaksandr Serzhputouski's Collection of Belarusian Proverbs (Sobranie belorusskikh poslovits i pogovorok), which was compiled by 1908 but was never published and is only available as a manuscript in the Archive of the Institute of Art Studies, Ethnography and Folklore of the Belarusian Academy of Sciences.

2 This is a typical dog's name in Russian-speaking countries.

3 Available at https://talks.by/showthread.php?t=2532253\&page=89\&, last accessed on 26 January 2018. 
4 Available at https://talks.by/showthread.php?t=2532253\&page=133, last accessed on 26 January 2018.

5 Available at https://talks.by/showthread.php?t=2532253\&page=154, last accessed on 26 January 2018.

${ }^{6}$ Available at https://talks.by/showthread.php?t=2532253\&page=49\&, last accessed on 26 January 2018.

7 Available at https://talks.by/showthread.php?t=2532253\&page=169, last accessed on 26 January 2018.

${ }^{8}$ Available at https://talks.by/showthread.php?t=2532253\&page=67\&, last accessed on 26 January 2018.

9 Available at https://talks.by/showthread.php?t=2532253\&page=77\&, last accessed on 26 January 2018.

${ }^{10}$ Available at https://talks.by/showthread.php?t=2532253\&page=190, last accessed on 26 January 2018.

${ }^{11}$ Available at https://forum.onliner.by/viewtopic.php?t=1020293\&start=2180, last accessed on 26 January 2018.

12 "Pilite, Ira, pilite" - a modified quote from the film adaptation of the famous satirical novel Golden Calf by Ilf and Petrov, many phrases from which have entered common use.

${ }^{13}$ The Twelve Chairs is another famous novel by Ilf and Petrov.

14 The interviewee likens the ashes on the barbecue to activated charcoal, which is commonly used in Belarus to treat digestion problems.

15 There is a belief among Belarusians that those who are in love oversalt the dishes they cook.

\section{MANUSCRIPT SOURCES}

Materials of interviews conducted in 2016 and 2017 in possession of the author. 


\section{REFERENCES}

Adler, Thomas A. 1981. Making Pancakes on Sunday: The Male Cook in Family Tradition. Western Folklore, Vol. 40, No. 1, pp. 45-54. http://dx.doi.org/10.2307/1499848.

Alvesson, Mats 2003. Beyond Neopositivists, Romantics, and Localists: A Reflexive Approach to Interviews in Organizational Research. The Academy of Management Review, Vol. 28, No. 1, pp. 13-33. http://dx.doi.org/10.2307/30040687.

Arnold, Oren 1972. Sourcebook of Family Humor. Grand Rapids, MI: Kregel Publications. Attardo, Salvatore 2014. Encyclopedia of Humor Studies. Thousand Oaks: SAGE Publications.

Attardo, Salvatore 2015. Humor and Laughter. In: Deborah Tannen \& Heidi E. Hamilton \& Deborah Schiffrin (eds.) The Handbook of Discourse Analysis. Second edition. Chichester: Wiley Blackwell, pp. 168-188.

Barbe, Katharina 1995. Irony in Context. Amsterdam \& Philadelphia: John Benjamins Publishing. http://doi.org/10.1075/pbns.34.

Billig, Michael 2005. Laughter and Ridicule: Towards a Social Critique of Humour. London \& Thousand Oaks \& New Delhi: SAGE.

Brzozowska, Dorota 2012. Family in Polish Jokes. In: Liisi Laineste \& Dorota Brzozowska \& Władysław Chłopicki (eds.) Estonia and Poland: Creativity and Tradition in Cultural Communication. Volume 1: Jokes and Their Relations. Tartu: ELM Scholarly Press, pp. 53-72. DOI: 10.7592/EP.1.dorota.brzozowska.

Davies, Christie 2011. Jokes and Targets. Bloomington \& Indianapolis: Indiana University Press.

Fiadosik, Anatol (ed.) 2005 [1984]. Zharty, Anekdoty, Gumareski. [Jokes, Anecdotes, Witticisms.] Minsk: Belaruskaya Navuka.

Geertz, Clifford 1973. The Interpretation of Cultures. New York: Basic Books.

Holbek, Bengt 1990. The Family Anecdote: Event and Narrative. In: L. Röhrich \& S. Wienker-Piepho (eds.) Storytelling in Contemporary Societies. Tübingen: Gunter Narr Verlag, pp. 103-112.

Korzun, Ivan 1992 [1976]. Belorusskaia kukhnia. [Belarusian Cuisine.] Minsk: Uradzhai.

Laineste, Liisi 2012. Women in Estonian Jokes. In: Liisi Laineste \& Dorota Brzozowska \& Władysław Chłopicki (eds.) Estonia and Poland: Creativity and Tradition in Cultural Communication. Volume 1: Jokes and Their Relations. Tartu: ELM Scholarly Press, pp. 33-52. DOI: 10.7592/EP.1.laineste.

Melnichenko, Mikhail 2014. Sovetskii anekdot (ukazatel' siuzhetov). [The Soviet Joke: Plots Classification.] Moscow: Novoe literaturnoe obozrenie.

Narodnyja 1961 = Narodnyja usmeshki: zbornik. [Folk Smiles: Anthology.] Minsk: Zviazda.

Navagrodski, Tadevush 2000. Tradycyi Narodnaga Kharchavannya Belarusau. [The Traditions of Belarusian Folk Cuisine.] Minsk: Nacyjanalny Instytut Adukacyi.

Navagrodski, Tadevush \& Makouskaya, Iryna \& Gurko, Aliaksandra \& Alyunina, Iryna \& Valodzina, Taccyana \& Zakharkevich, Scyapan \& Kilbas, Aliaksandr \& Kukharonak, Taccyana \& Makhnach, Alyaksei \& Myadzyanik, Uladzimir \& Tserashkovich, Pavel \& Chakvin, Igar \& Shumski, Kanstancin \& Yakubinskaya, Alesya 2009. Etnalogiya Belarusi: Tradycyjnaja Kultura Nasel'nictva 
u Gistarychnaj Perspectyve. [Belarusian Ethnology: Traditional Culture of the Population in Historical Perspective]. Minsk: BDU.

Oring, Elliott 1984. Dyadic Traditions. Journal of Folklore Research, Vol. 21, No. 1, pp. 19-28. Available at http://www.jstor.org/stable/i291295, last accessed on 26 January 2018.

Oring, Elliott 2003. Engaging Humor. Champaign: University of Illinois Press.

Raskin, Victor 1985. Semantic Mechanisms of Humor. Dordrecht: D. Reidel. DOI: 10.3765/ bls.v5i0.2164.

Samakhval, Siargei 2011. Ezha Yak Kulturna-nacyjanal'ny Aspekt Zhyccya (na prykladze paremiyalagichnykh dadzenykh belaruskaj movy). [Food as a Cultural and National Aspect of Life (on Paremiological Material of Belarusian Language).] In: Ivan Rouda (ed.) Fal'klor i suchasnaja kul'tura: materyjaly III Mizhnarodnaj navukova-praktychnaj kanferencyi 21-22 krasavika 2011, Minsk. [Folklore and Modern Culture: The Proceedings of the Third International Academic Conference, April 21-22, 2011, Minsk.] Vol. 2. Minsk: Vydavecki centr BDU, pp. 114-116.

Schofield, Mary Anne (ed.) 1989. Cooking by the Book: Food in Literature and Culture. Bowling Green, Ohio: Bowling Green State University Popular Press.

Shosteck, Patti 1979. A Lexicon of Jewish Cooking: A Collection of Folklore, Foodlore, History, Customs, and Recipes. Chicago: Contemporary Books.

Skaarup, Bi 2013. The New Nordic Diet and Danish Food Culture. In: P. Lysaght \& H. Jönsson \& A. Burstedt (eds.) The Return of Traditional Food. Lunds Studies in Arts and Cultural Sciences, Vol. 1. Lund: Lund University, pp. 43-52. Available at http://portal.research.lu.se/ws/files/3761338/4053890.pdf, last accessed on 26 January 2018.

Smith, Moira 2009. Humor, Unlaughter, and Boundary Maintenance. Journal of American Folklore, Vol. 122, No. 484, pp. 148-171. http://dx.doi.org/10.1353/ jaf.0.0080.

Thielemann, Nadine 2011. Displays of "New" Gender Arrangements in Russian Jokes. In: M. Dynel (ed.) The Pragmatics of Humour Across Discourse Domains (Pragmatics \& Beyond New Series, Vol. 210). Amsterdam \& Philadelphia: John Benjamins Publishing, pp. 147-172.

Walsh, Froma 2015. Strengthening Family Resilience. Third edition. New York \& London: Guilford Press.

Zajdman, Anat 1991. Contextualization of Canned Jokes in Discourse. Humor International Journal of Humor Research, Vol. 4, No. 1, pp. 23-40. http://dx.doi. org/10.1515/humr.1991.4.1.23. 


\section{INTERNET SOURCES}

Anekdoty pro Sol'. [Jokes about Salt.] Available at http://anekdoty.ru/pro-sol/, last accessed on 26 January 2018.

Lyubimye anekdoty!!! [Favourite Jokes!!!] Available at http://forum.onliner.by/viewtopic. php?t=1020293, last accessed on 26 January 2018.

Svezhij anekdot. [Fresh Joke.] Available at http://talks.by/showthread.php?t=2532253, last accessed on 26 January 2018. 